\title{
Endoscopic management of urethral trauma in male spinal cord injury patients
}

\author{
S Vaidyanathan, KR Krishnan and BM Soni \\ Regional Spinal Injuries Centre, DGH, Southport, Merseyside PR8 6PN, UK
}

\begin{abstract}
Spinal cord injury (SCI) patients with a neuropathic bladder are more prone to develop catheter-induced urethral trauma than occurs in the general population because many of the SCI patients are on indwelling urethral catheter drainage, or intermittent urethral catheterisation is performed either by them or by their carers. The presenting symptoms of improperly positioned Foley catheter in SCI patients may be at times, peculiar to the SCI patients and these include profuse sweating, bypassing of the catheter, increased spasms, or rarely, full fledged features of autonomic dysreflexia. With the availability of the flexible cystoscope, cystourethroscopy has been performed safely on SCI patients who had sustained catheter-induced urethral trauma, on the bedside, with an immediate, and accurate diagnosis of the extent of urethral trauma, and the presence of urethral false passage(s). Further, flexible cystoscopy has helped to treat the patients with urethral trauma by introducing a flexible tip guide wire under vision into the urinary bladder via the normal urethral channel and subsequently, passing a $12 \mathrm{Fr}$. Foley catheter over the guide wire, thus avoiding the false passage(s) in the urethra. With this technique, it was possible to avert the need for suprapubic urinary diversion in those SCI patients who had sustained acute urethral trauma. Such endoscopic management of acute urethral trauma in SCI patients is described with illustrative case reports of eight patients seen during a 15 month period.
\end{abstract}

Keywords: spinal cord injury; urethra, rupture; false urethral passage; cystoscopy, flexible

\section{Introduction}

Male spinal cord injury patients with a neuropathic bladder are usually managed by indwelling urethral catheter drainage during the immediate post-trauma period. Subsequently, they may either perform intermittent urethral catheterisation, or continue to be on indwelling urethral catheter drainage, or they may be established on penile condom drainage when they recover bladder function following spinal cord injury which is dependent upon the reorganization of reflex pathways in both the peripheral and central nervous system, provided reflex voiding occurs with no evidence of detrusor-sphincter dyssynergia. While spinal cord injury patients are on indwelling urethral catheter drainage, the urethral Foley catheter requires replacement whenever it is (partially) blocked or at 3 to 8 weeks intervals depending on the type of catheter used (whether teflon-coated latex, silicone elastomercoated latex or all silicone Foley catheter is used). When the catheter gets blocked especially at odd hours, the person changing the urethral catheter may not be familiar with the intricacies of the care of spinal cord

Correspondence: Dr S Vaidyanathan, Regional Spinal Injuries Centre, District General Hospital, Town Lane, Kew, Southport, PR8 6PN, Merseyide, UK injury patients. Sometimes, the clinical symptoms of a wrongly positioned Foley catheter may be peculiar to spinal cord injury patients. For example, profuse sweating may be the sole clinical manifestation of an improperly placed catheter resulting in a partly distended urinary bladder in a tetraplegic patient. Such a symptom is never seen under similar circumstances in the case of an adult male with an intact neuraxis. Similarly, bypassing the catheter may be the presenting clinical feature of an incorrectly placed urethral Foley catheter. Another uncommon, but more serious symptom complex of an incorrectly positioned urethral catheter with unsatisfactory drainage of urinary bladder, seen exclusively in spinal cord injury patients with lesions above $\mathrm{T}-6$, is that of autonomic dysreflexia. Although the acute symptoms of autonomic dysreflexia, viz. hypertension, flushing, and headache may be treated satisfactorily by immediate sublingual administration of 10 milligrams of nifedipine, recurrence of dysreflexic symptoms cannot be prevented unless the underlying cause is identified and appropriate corrective measures (repositioning of the urethral catheter with provision of satisfactory drainage of the urinary bladder) are instituted without delay. 
Table 1 Resume of the clinical details of the eight paraplegic/tetraplegic patients who developed catheter-induced urethral trauma, and outcome of endoscopic management of acute urethral trauma in these patients

\begin{tabular}{|c|c|c|c|c|c|}
\hline $\begin{array}{l}\text { Patient } \\
\text { number } \\
\text { and date } \\
\text { of birth }\end{array}$ & $\begin{array}{l}\text { Clinical diagnosis } \\
\text { and date of onset } \\
\text { of paralysis }\end{array}$ & $\begin{array}{l}\text { Method of } \\
\text { urinary bladder } \\
\text { drainage prior to } \\
\text { urethral trauma }\end{array}$ & $\begin{array}{l}\text { Presenting symptoms when ure- } \\
\text { thral trauma had occurred during } \\
\text { catherterisation. Relevant clinical } \\
\text { and radiological signs }\end{array}$ & Findings during flexible cystoscopy & $\begin{array}{l}\text { Outcome of endoscopic management of } \\
\text { urethral trauma }\end{array}$ \\
\hline $\begin{array}{l}1 \\
30-04- \\
1937\end{array}$ & $\begin{array}{l}\text { Disc prolapse } \\
\text { L5/S1 } \\
\text { Incomplete } \\
\text { paraplegia since } \\
\text { 10-03-1995 }\end{array}$ & $\begin{array}{l}\text { Intermittent } \\
\text { urethral } \\
\text { catheterisation }\end{array}$ & $\begin{array}{l}\text { 1. Inability to pass a catheter } \\
\text { per urethra } \\
\text { 2. Urethral bleeding }++\end{array}$ & $\begin{array}{l}\text { Flexible cystoscopy revealed multiple false } \\
\text { passages in the bulbous urethra }\end{array}$ & $\begin{array}{l}\text { 1. Following indwelling urethral catheter } \\
\text { drainage for about } 10 \text { weeks, he is now able } \\
\text { to perform self-catheterisation satisfactorily } \\
\text { 2. No urethral stricture }\end{array}$ \\
\hline $\begin{array}{l}2 \\
27-11- \\
1944\end{array}$ & $\begin{array}{l}\text { Traumatic } \\
\text { tetraplegia C5/6 } \\
\text { since 29-07-1989 }\end{array}$ & $\begin{array}{l}\text { Indwelling } \\
\text { urethral } \\
\text { catheter } \\
\text { drainage }\end{array}$ & $\begin{array}{l}\text { 1. The newly inserted urethral } \\
\text { catheter was not draining urine. } \\
\text { 2. Sweating }++ \\
\text { 3. Bypassing }++\end{array}$ & $\begin{array}{l}\text { Flexible cystoscopy revealed a long false } \\
\text { passage in the prostatic urethra }\end{array}$ & $\begin{array}{l}\text { 1. Following indwelling urethral catheter } \\
\text { drainage, there has been partial healing of } \\
\text { the false passage. As the catheter tends to } \\
\text { poke into the false passage instead of going } \\
\text { past it into the bladder, flexible cystoscopy } \\
\text { has been used for catheter insertion } \\
\text { subsequently } \\
\text { 2. He continues to be on indwelling } \\
\text { urethral catheter drainage }\end{array}$ \\
\hline $\begin{array}{l}3 \\
29-05- \\
1934\end{array}$ & $\begin{array}{l}\text { Traumatic } \\
\text { tetraplegia C5/6 } \\
\text { since } 29-06 \\
1983\end{array}$ & $\begin{array}{l}\text { Indwelling } \\
\text { urethral } \\
\text { catheter } \\
\text { drainage }\end{array}$ & $\begin{array}{l}\text { 1. The newly inserted catheter } \\
\text { was not draining urine } \\
\text { 2. Sweating }++\end{array}$ & $\begin{array}{l}\text { Flexible cystoscopy revealed that the Foley } \\
\text { balloon had been inflated in the bulbous } \\
\text { urethra }\end{array}$ & $\begin{array}{l}\text { Following indwelling urethral catheter } \\
\text { drainage, the pseudo-cavity has undergone } \\
\text { resolution partly. As the catheter tends to } \\
\text { curl inside the dilated bulbous urethra, } \\
\text { flexible cystoscopy has been used for } \\
\text { catheter insertion subsequently }\end{array}$ \\
\hline $\begin{array}{l}4 \\
24-01- \\
1964\end{array}$ & Spina bifida & $\begin{array}{l}\text { Indwelling } \\
\text { urethral } \\
\text { catheter } \\
\text { drainage }\end{array}$ & $\begin{array}{l}\text { 1. The newly inserted catheter } \\
\text { was not draining urine } \\
\text { 2. Catheter Bypassing }++\end{array}$ & $\begin{array}{l}\text { The Foley balloon had been inflated in } \\
\text { the false passage arising from the } \\
\text { prostatic urethra; the tip of the Foley } \\
\text { catheter was outside the urinary bladder. } \\
\text { A new } 12 \mathrm{Fr} \text {. Foley catheter was } \\
\text { inserted with flexible cystocope }\end{array}$ & $\begin{array}{l}\text { 1. The Foley catheter started draining urine } \\
\text { satisfactorily and bypassing stopped } \\
\text { completely } \\
\text { 2. He continues to be on indwelling urethral } \\
\text { catheter drainage }\end{array}$ \\
\hline $\begin{array}{l}5 \\
19-02- \\
1929\end{array}$ & $\begin{array}{l}\text { Traumatic } \\
\text { paraplegia T-10 } \\
\text { since 15-08- } \\
1956\end{array}$ & $\begin{array}{l}\text { Indwelling } \\
\text { urethral } \\
\text { catheter } \\
\text { drainage }\end{array}$ & $\begin{array}{l}\text { 1. Multiple unsuccessful } \\
\text { attempts to pass an indwelling } \\
\text { urethral catheter } \\
\text { 2. Urethral bleeding }+++\end{array}$ & $\begin{array}{l}\text { Flexible cystoscopy revealed multiple } \\
\text { urethral false passages. Indwelling } \\
\text { urethral catheter drainage was } \\
\text { established uneventully with the flexible } \\
\text { cystoscope and guide wire technique }\end{array}$ & $\begin{array}{l}\text { He continues to be on indwelling urethral } \\
\text { catheter drainage awaiting incomplete healing } \\
\text { of the false passages }\end{array}$ \\
\hline $\begin{array}{l}6 \\
13-06- \\
1938\end{array}$ & $\begin{array}{l}\text { Traumatic } \\
\text { paraplegia T-8 } \\
\text { since 06-02- } \\
1961\end{array}$ & $\begin{array}{l}\text { Indwelling } \\
\text { urethral } \\
\text { catheter } \\
\text { drainage }\end{array}$ & $\begin{array}{l}\text { Excision of urethral diverticulum } \\
\text { and urethral repair had been done } \\
8 \text { weeks ago. Urethral } \\
\text { catheterisation unsuccessful; } \\
\text { Urethral bleeding }+\end{array}$ & $\begin{array}{l}\text { Flexible cystoscopy revealed that during } \\
\text { attempts at blind catheterisation, the } \\
\text { Foley catheter had been poking into the } \\
\text { remnant of the urethral diverticulum } \\
\text { instead of going past it into the urinary } \\
\text { bladder }\end{array}$ & $\begin{array}{l}\text { After a short period of indwelling catheter } \\
\text { drainage, he is being maintained on penile } \\
\text { condom drainage }\end{array}$ \\
\hline
\end{tabular}


Table 1 cont

\begin{tabular}{|c|c|c|c|c|c|}
\hline $\begin{array}{l}7 \\
24-10- \\
1968\end{array}$ & $\begin{array}{l}\text { Traumatic } \\
\text { paraplegia T-5 } \\
\text { since 01-09- } \\
1995\end{array}$ & $\begin{array}{l}\text { Intermittent } \\
\text { self } \\
\text { catheterisation } \\
\text { with size } 12 \mathrm{Fr} \text {. } \\
\text { PVC catheter }\end{array}$ & $\begin{array}{l}\text { 1. Urethral catheterisation } \\
\text { unsuccessful } \\
\text { 2. Urethral bleeding }++\end{array}$ & $\begin{array}{l}\text { Flexible cystoscope showed a false } \\
\text { passage in the bulbous urethra just } \\
\text { distal to the sphincter. Indwelling } \\
\text { urethral catheter drainage was } \\
\text { established uneventfully with the } \\
\text { flexible cystoscope and guide wire } \\
\text { technique }\end{array}$ & $\begin{array}{l}\text { After } 2 \text { months, flexible cystoscopy } \\
\text { revealed that the false passage had healed. } \\
\text { He could then satisfactorily perform } \\
\text { intermittent, self-catherterisation with } \\
\text { LOFRIC size } 10 \text { Fr. catheter }\end{array}$ \\
\hline $\begin{array}{l}8 \\
05-06- \\
1976\end{array}$ & Spina bifida & $\begin{array}{l}\text { Indwelling } \\
\text { urethral } \\
\text { catheter drainage } \\
\text { Episodes } \\
\text { of urethral } \\
\text { bleeding } \\
\text { during } \\
\text { catheter } \\
\text { changes }\end{array}$ & $\begin{array}{l}\text { 1. Bypassing of the catheter } \\
\text { 2. Excessive length of the Foley } \\
\text { catheter was lying outside the } \\
\text { urethra. } \\
\text { 3. Inability to perform } \\
\text { self-catheterisation as the tip of } \\
\text { the catheter would tend to coil } \\
\text { inside the cavity in the } \\
\text { urethra instead of getting past it } \\
\text { and entering the bladder neck } \\
4 \text {. Intravenous urography revealed } \\
\text { that the balloon of the Foley catheter } \\
\text { was located in the prostato-membra- } \\
\text { nous urethra, Normal appearances of } \\
\text { the bladder neck and proximal prostatic } \\
\text { urethra }\end{array}$ & $\begin{array}{l}\text { Flexible cystoscopy confirmed the } \\
\text { radiological findings. Indwelling urethral } \\
\text { catheter drainage was established } \\
\text { uneventfully with the flexible cystoscope } \\
\text { and guide wire technique. Bypassing } \\
\text { of the catheter stopped immediately } \\
\text { thereafter } \\
\text { d } \\
\text { r } \\
\text { c }\end{array}$ & $\begin{array}{l}\text { He continues to be on indwelling urethral } \\
\text { catheter drainage pending healing and } \\
\text { shrinkage of the cavity created by forcible } \\
\text { inflation of the balloon of the Foley catheter } \\
\text { in the prostato-membranous urethra }\end{array}$ \\
\hline
\end{tabular}

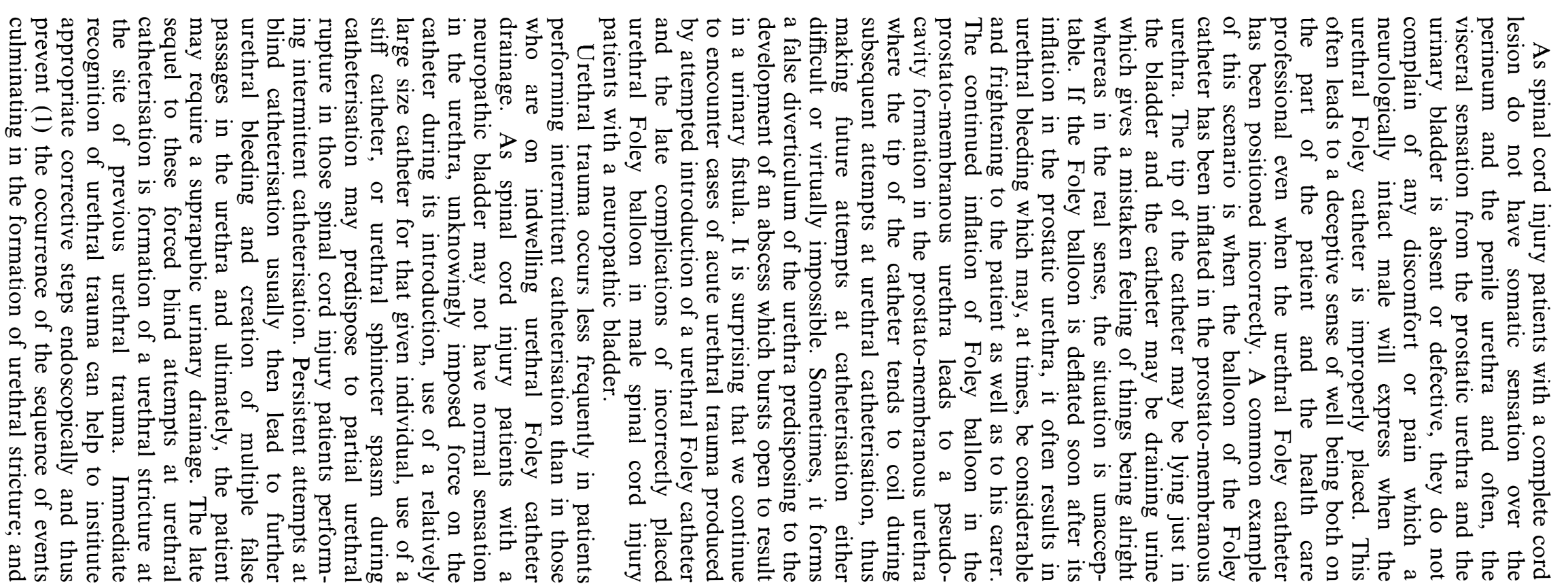


(2) the need for suprapubic urinary diversion. Although suprapubic cystostomy has been the cornerstone in the management of urethral trauma, with the advent of flexible cystoscope, a stenting catheter can be introduced over a guide wire inserted under vision through the urethra avoiding false passage(s). Flexible cystoscopy can be performed in the ward/clinic area with the patient either in the supine position on a bed or sitting up on his chair. Flexible cystoscopy does not require general or regional anaesthesia, a great advantage to the tetraplegic patient who is often a poor risk candidate for emergency anaesthesia. Further, the spinal cord injury patient need not be positioned in lithotomy which often is the case for cystoscopic insertion of urethral catheter with a rigid instrument. We managed eight spinal cord injury patients with catheter-induced urethral trauma endoscopically with satisfactory outcome, during a 15 month period; such a large number of patients sustaining urethral trauma due to catheterisation is a reflection of the magnitude of this problem amongst spinal cord injury patients. This prompted us to describe the technical details of the diagnosis and endoscopic management of acute urethral trauma with the use of a flexible cystoscope so that physicians and nursing staff caring for spinal cord injury patients in specialised spinal injury centres and in accident and emergency departments of a district general hospital are able to recognise the occurrence of urethral trauma during catheterisation, document the presence of false passage(s) and the faulty positioning of Foley balloon, and institute appropriate treatment without delay. As flexible cystoscopy is performed without anaesthesia in the ward, the patient need not be transported to the operating room and he can be sent home soon after the procedure; hence flexible cystoscopy becomes costeffective in the long-term although the initial cost of its procurement may be high.

\section{Case reports}

During the period of 15 months, we treated eight patients who had sustained urethral trauma during catheterisation in the Regional Spinal Injuries Centre, Southport; six of them were on indwelling urethral catheter drainage and urethral trauma occurred during attempts at insertion of a new Foley catheter after the blocked catheter had been removed; two patients sustained urethral trauma during intermittent catheterisation. The clinical details of these eight patients who developed urethral trauma during cathetersiation, their presenting symptoms, and immediate as well as longterm outcome of endoscopic management of acute urethral trauma are summarised in Table 1. Flexible cystoscopy was performed in the ward/clinic in these patients without incurring any additonal morbidity. Both the tetraplegic patients withstood the procedure of flexible cystoscopy performed at the bedside (many times) and they did not develop symptoms of autonomic dysreflexia during cystoscopy. The patient's blood pressure and heart rate were automatically recorded every minute with CRITIKON DINAMAP Vital Signs Monitor 1846 SX during the endoscopic procedure. Precaution was taken to avoid distension of the urinary bladder during cystoscopy as it could precipitate autonomic dysreflexia in susceptible patients. Nifedipine $10 \mathrm{mg}$ was kept ready to be administered sublingually, should blood pressure increase to more than $150 / 90 \mathrm{mmHg}$ during the endoscopic procedure.

\section{Technique of endoscopic management urethral trauma} The patient is resting comfortably on the bed with all the precautions taken to avoid pressure markings. Olympus CYF-3 flexible cystoscope is used which has an outside diameter of distal end of $5.4 \mathrm{~mm}$; field of view of $120^{\circ}$; direction of view of $0^{\circ}$ (forward viewing); depth of view of $3-50 \mathrm{~mm}$; and instrument channel of $2.2 \mathrm{~mm}$. In contrast to the recommendations of Rivas and Chancellor, ${ }^{2}$ we always use sterile $0.9 \%$ sodium chloride solution intended for intravenous use as the irrigant for flexible cystoscopy. Use of sterile physiological saline for irrigation has ensured that any absorption or extravasation of the irrigant, or urethro-venous reflux which are likely to occur in cases of partial urethral rupture does not result in any additional morbidity to the spinal cord injury patient $v i z$. systemic sepsis or local periurethral infection, or dilutional hyponatremia; the latter entity may occur very rarely when sterile water is used as the irrigant and large amounts of the irrigant are absorbed during the endoscopic procedure. ${ }^{3}$ As spinal cord injury patients are already prone to develop hyponatremia, ${ }^{4}$ we are very cautious and would avoid any other predisposing factor for the development of hyponatremia (such as the use of distilled water for endoscopy), in the SCI patients. We did not feel the need for use of any lubricant for flexible cystoscopy in spinal cord injury patients; it should be remembered that petroleum based lubricants will cause stretching and deterioration of bending section rubber of the cystoscope.

The cystoscope is advanced up to the site of urethral trauma. The extent of urethral laceration, number and direction of false passage(s), and presence if any, of a pseudo-cavity (due to forced inflation of Foley balloon either in the urethra or in the false passage) are noted. A guide wire of 0.038 " diameter is introduced through the instrument channel of the flexible cystoscope and then advanced till the flexible tip of the guide wire is seen protruding just beyond the cystoscope. The false passage(s) are identified; the flexible tip of the guide wire is advanced gently through the normal urethral channel till the guide wire is coiled inside the bladder. No resistance should be felt while advancing the flexible tip of the guide wire through the normal urethral passage. The cystoscope is then withdrawn leaving the guide wire curled up inside the bladder. A size $12 \mathrm{Fr}$. all silicone 
Foley catheter is threaded over the guide wire after punching a hole of $2-3 \mathrm{~mm}$ size at the tip of the catheter with Cook Foley Catheter Tip Punch (Code no. 053000 , Cook UK Ltd.) for introducing the guide wire into the lumen of the Foley catheter. The catheter is advanced to its full length and then the Foley balloon is inflated after ensuring free drainage of urine/accumulated irrigating fluid from the urinary bladder. After the balloon is inflated and the catheter is positioned properly inside the bladder, the guide wire is gently withdrawn. We prefer to use a size 12 Fr. all silicone catheter except in those patients with significant haematuria in whom, a larger sized catheter will be indicated so that the catheter lumen is not blocked with blood clot. The patient is administered gentamicin $80 \mathrm{mg}$ intravenously. $\mathrm{He}$ is observed for another $30 \mathrm{~min}$ for occurrence if any, of (1) temperature, (2) urethral bleeding, (3) haematuria, (4) rigors, (5) vomiting. In the absence of any of these features, he is sent home with antibiotics to be taken by mouth for 5 days.

In patients who were performing intermittent catheterisation prior to this episode of urethral trauma, the Foley catheter is removed after 6-8 weeks and flexible cystoscopy is performed to assess healing of the urethral laceration and closure of false passage(s). We have found satisfactory healing of urethral laceration and spontaneous closure of urethral false passages after 6-8 weeks of indwelling urethral stenting catheter drainage with no evidence of stricture formation. The patient then performs self-catheterisation with a LOFRIC catheter of size $10 \mathrm{Fr}$. under supervision. If he can perform catheterisation satisfactorily and there is no urethral bleeding, he continues to perform self-catheterisation with size $10 \mathrm{Fr}$. catheter. But if the patient found catheterisation difficult, or if there is urethral bleeding during catheterisation, we advise indwelling urethral catheter drainage for another 6-8 week period. In case of those spinal cord injury patients in whom the Foley balloon had been forcibly inflated in the urethra or in the false passage, indwelling urethral catheter is removed after 6-8 weeks and a new size $12 \mathrm{Fr}$. Foley catheter is introduced into the bladder over a guide wire with the help of flexible cystoscope as per the technique described above. The pseudo-cavity created by forcible inflation of Foley balloon in the prostato-membranous urethra or a false passage takes a longer period than 6-8 weeks to undergo complete resolution although some amount of urethral dilation may persist even after many months. We feel that blind insertion of Foley catheter may not be safe in these patients for the next 6 to 12 months or even longer. Therefore, we perform subsequent catheter changes with the help of flexible cystoscope to prevent recurrence of the same problem viz. the catheter tip curling up inside the dilated prostato-membranous urethra or the catheter tip poking into the false passage which has not sealed off completely.

\section{Discussion}

Beaghler et $a l^{5}$ described the use of flexible cystoscopy to pass a urethral catheter in a general urological service. Their technique consisted of (1) passing a 0.038 inch guide wire past the area of false passage; (2) the cystoscope is removed and Nottingham dilators are then fed over the guide wire in a sequential fashion, first from 6-12 Fr. and then 12 to $18 \mathrm{Fr}$; (3) after urethral dilation, a 16 Fr. Council-tipped catheter is fed over the guide wire. In our clinical practice related to the management of acute urethral trauma in spinal cord injury patients, we did not observe the need to use urethral dilators in any of our patients. We prefer to use a small size catheter ( $12 \mathrm{Fr}$. all silicone Foley catheter) except in those who have significant haematuria. With this protocol of using a small size urethral catheter, we are able to prevent the complications of indwelling urethral catheter drainage (viz. periurethral abscess, urethral diverticulum, urinary fistula, urethral stricture, epididymitis, and orchitis) to a great extent. As we generally introduce only a 12 Fr. Foley catheter over the guide wire, and do not perform urethral dilation, the chances of urethral bleeding and gram-negative sepsis originating from the urinary tract are greatly minimised. Therefore, we are able to send the patients soon after the procedure to their own residential homes thus averting the need for hospitalisation. By adopting this protocol of management, the use of flexible cystoscopy to place an indwelling urethral catheter in cases of acute urethral trauma in spinal cord injury patients becomes costeffective. Although the classical management of urethral trauma in patients practising intermittent catheterisation during the pre-flexible cystoscopy era was immediate suprapubic urinary diversion and later, visual internal urethrotomy of the urethral stricture, ${ }^{6}$ with the availability of the flexible cystoscope, improved clinical results have been obtained by adopting such a protocol of immediate endoscopic management as described in this study in those spinal cord injury patients who had sustained catheter-induced urethral trauma.

During the past few years, we have been adopting intermittent urethral catheterisation with adjuvant pharmacotherapy by oral or intravesical oxybutynin ${ }^{7}$ when indicated, as the treatment of choice for management of neuropathic bladder in spinal cord injury patients whenever feasible, and this regimen has resulted in fewer urinary complications in patients performing intermittent catheterisation as compared to those patients who have been on indwelling urethral catheter drainage. Biofilm can be detected on the surface of chronic indwelling urinary catheters and the initial step in struvite calculogenesis is the adherence of urealytic bacteria (particularly Proteus mirabilis) to Foley catheters. ${ }^{8}$ A sudden elevation of the pressure in the urinary collecting system as occurs during blockage of Foley catheter results in mechanical introduction of bacteria in biofilm into the kidney and blood vessels which may be followed by urosepsis. 
Hopefully, by avoiding indwelling urinary catheters in spinal cord injury patients, urethral trauma associated with catheterisation (as seen in six of the eight cases

reported herein), and catheter-associated urinary infections (in which bacterial biofilms play a considerable role) can be minimised.

\section{References}

1 de Groat WC. Mechanisms underlying the recovery of lower urinary tract function following spinal cord injury. Paraplegia 1995; 33: $493-505$.

2 Rivas DA, Chancellor MB. Flexible cystoscopy in spinal cord injury. Review article. Paraplegia 1994; 32: 454-462.

3 Batra YK, Kapoor R, Hemal AK, Vaidyanathan S. Hyponatremia and mental symptoms following vesical ultrasonic lithotripsy. Anaesthesia 1988; 43: 675-676.

4 Soni BM, Vaidyanathan S, Watt JWH, Krishnan KR. A retrospective study of hyponatremia in tetraplegic/paraplegic patients with a review of literature. Paraplegia 1994; 32: 597 607.

5 Beaghler M, Grasso M, Loisides P. Inability to pass a urethral catheter: The bedside role of the flexible cystoscopy. Urology 1994; 44: $268-270$. 